\title{
The Moderating Effect of Corruption on Deterrent and Socio- Psychological Factors for Tax Compliance: A Conceptual Model for Small and Medium Enterprises in Uganda
}

\author{
Festo Nyende Tusubira ${ }^{*} \quad$ Jude Thaddeo Mugarura ${ }^{2}$ \\ 1.Department of Accounting and Finance, College of Business and Management Sciences, Makerere University, \\ P.O. Box 7062, Kampala, Uganda \\ 2.Department of Marketing and Management, College of Business and Management Sciences, Makerere \\ University, P.O. Box 7062, Kampala, Uganda
}

\begin{abstract}
Tax compliance is the desire for every nation world over. Although investigations have been done into the effects of deterrent and social psychological factors on tax compliance, inconsistent results have been reported, suggesting that a moderator might explain the mixed results. Intrinsically, the main aim of this research is to propose the addition of the perceptions of corruption as having a role to play in moderating the relationships between first, deterrent factors and tax compliance and second, the social psychological factors and tax compliance behaviour among SMEs in Uganda. Once validated, the proposed model will be valuable to government in policy formulations and evaluation, Uganda Revenue Authority and other regulatory bodies, and practitioners.
\end{abstract}

Keywords: corruption, Uganda, tax compliance, deterrent factors, trust, social factors, SMEs

DOI: $10.7176 / \mathrm{EJBM} / 12-22-07$

Publication date:August $31^{\text {st }} 2020$

\section{Introduction}

Tax compliance is a major global concern that policy makers continue to grapple with in both developing and developed nations. Yet, raising public revenue to finance public expenditure arrangements, for instance infrastructure provision is one of the ultimate objectives of taxation, notwithstanding the level of economic development (Coolidge, Ilic \& Kisunko 2009; Hansford \& Hasseldine 2012; Lignier \& Evans 2012; Cidália 2012). According to Slemrod (1992), scholarly works have focused more on the non-compliance than compliance of tax payers to the laws. This seems to stem from the assumption that majority of the taxpayers hate paying taxes (Dare, Du Plessis \& Jansen 2019). This view is supported by the Guardian (2018) who reveals that the United Kingdom's (UK) has to counter the arrogance of the Tech firms, such as Google, Facebook and Amazon, for not complying with the tax laws in place. This has been done by introducing a 2 percent tax charge on the UK revenue, following the losses the government incurs through the transfer pricing mechanism that such firms use to reduce their profits (Iftikhar et al. 2015). Equally, African countries seem to suffer the biggest loss from illicit financial flows due to potential weaknesses in tax transparency (OECD 2018), losing up to USD 80 billion by 2018.

The Republic of Uganda in particular, has low levels of tax compliance especially among the small and medium-sized enterprises, notwithstanding the enforcement mechanisms like sanctions, tax audits and investigations by Uganda Revenue Authority (URA) office and the Tax Appeals Tribunal (Tusubira, 2018). According to Asingwire (2019) tax compliance among SMEs continues to be an atrocious job to attain. Tax evasion, for instance seems to be on an increase for SMEs (Verberne 2018). Uganda as a country has been lagging behind in most of the global social and economic development competitive indices. For instance, the 2019 World Economic Forum Global Competitive Report, Uganda ranked to $115^{\text {th }}$ position out of 141 economies studied with a score of 48.9 percent all due to flaws in the institutional infrastructure among other pillars of competitiveness (Klaus Schwab 2019) which might affect tax compliance among taxpayers. The corruption perception indices for the years 2012 to 2019 by Transparency International (TI) indicate that Uganda had the highest score of 29 in 2012 for a scale of $0-100,0$ as worst and 100 as best in the $130^{\text {th }}$ position out of 176 countries, and the least score of 25 between 2015 and 2016 respectively and a score of 28 in the year 2019 in the $137^{\text {th }}$ position out of 180 nations. These scores categorise Uganda among the worst countries in the control of corruption in the world. Also, the World Economic Forum 2017-2018 reveal that the most prominent problematic areas in doing business in Uganda are tax rates. However, corruption might affect the nature of tax administration in the country, thereby interfering with the tax compliance relationships.

Two major dimensions of the factors that influence tax compliance are; the deterrents (e.g. penalties, audit probability and detection, tax rates and tax complexity) (Becker, 1974; Allingham \& Sandmo, 1972, 1972; Kirchler, Hoelzl \& Wahl, 2008; Saad 2014; Saad, Udin \& Derashid 2014); and the social psychological considerations (e.g. tax fairness, trust in authorities, corruption, social norms and tax morale) (Torgler \& Schneider 2005; Kirchler et al. 2008; Bobek, Hageman \& Kelliher 2013; Tusubira \& Nkote 2013; Faizal, Palil, Maelah \& Ramli 2017). Apart from corruption, (See; Rosid, Evans \& Tran-Num 2016; Alm, Martinez-Vazquez \& McClellan, 2016; Schneider 
\& Torgler 2007), scholarly works continue to produce inconsistent and weak relationship results on the aforementioned variables (Raskolnikov 2009; Kogler, Muehlbacher \& Kirchler 2013; Dwenger, Kleven, Rasul \& Rincke 2016).

Yet contextually tax compliance continues to receive little empirical research attention in Uganda. While Tusubira \& Nkote (2013), Nkundabanyanga, Mvura, Nyamuyonjo, Opiso \& Nakabuye (2017), Musimenta, Nkundabanyanga, Muhwezi, Akankunda \& Nalukenge (2017) have investigated SMEs tax compliance in Uganda, none of them interrogates the effects of corruption perceptions in relation to tax compliance. Therefore, this study set out to investigate, the moderating influence of corruption perceptions on deterrent and social psychological factors towards SMEs tax compliance behaviour in Uganda. Introduction of corruption perceptions will help predict which variable (deterrent, and social psychological factors) has more influence on tax compliance behaviour (Kirchler et al., 2008; Muehlbacher \& Kirchler, 2010; Kastlunger, Lozza, Kirchler \& Schabmann 2013). Finally, a suitable model for SMEs tax compliance model will be developed and its applicability discussed.

\section{Theoretical and literature review}

\subsection{Tax compliance}

Tax compliance refers to the level at which taxpayers conform to the tax laws of a particular economy (Song \& Yarbrough 1978; Palil \& Mustapha 2011; Bruce-Twum 2014. As such, Tax compliance necessitates accurate reporting of the tax base, correct tax liability computation, and timely filing of returns and effecting of tax payments (Franzoni 2000; Kornhauser 2007). Nkwe (2012) expands the scope of tax compliance to registering for Tax Identification Numbers, preparing and keeping proper books of accounts, payment of tax fines welcoming tax audits and using competent tax advisors. Following the above views, tax compliance effectiveness seems to be twofold. The deferent measures that relate to compliance with tax laws, and the voluntary measures that are pegged on the social psychological tax demands (See; Kirchler et al. 2008; Braithwaite 2009; James \& Alley 2004). Therefore, tax compliance by tax payers is either voluntary or enforced or both. (OECD 2001).

We therefore contend that if the right authority is not properly recognised where taxpayers ought to file their returns, then noncompliance will have taken place. Secondly, in a developing country perspective where corruption is treasured, it would become an opportunity for taxpayers and corrupt tax officers as well as other government officers to divert such funds for personal purposes, including encouragement of total noncompliance irrespective of whether the taxpayer has made any payments to these officers. Following the above debate, and bearing in mind the framework in which we conduct this scholarship, we conceptualise tax compliance to mean the taxpayers ability to voluntarily comply with the tax code either due to their willingness to do so or by way of enforcement. This means that taxpayers should have the willingness and ability to declare the right incomes and tax liabilities to the right authorities either due to the level of trust that they have in the tax authorities arising from tax fairness or arising from enforcement mechanisms like audit rates, sanctions and tax rates among others. However, this notwithstanding, compliance might be interrupted if the effects of corruption are factored in as a moderating variable.

\subsection{Economic or deterrent factors and tax compliance}

\subsubsection{Audit probability, detection and tax compliance}

A number of scholars indicate there being a number of risks of being detected. For instance, Allingham and Sandmo model (1972) and those who advocate for the Fischer's model (1992), put further emphasis on the probability of detection of noncompliance (Bosco \& Mittone 1997), yet Alleyne \& Harris (2017) and Carnes \& Englebrecht (1995) put more prominence on perceived risk of detection. Allowing for the related conversations made by earlier scholars, the most conclusive and encompassing definition is that of Fischer, Wartick \& Mark (1992) which proposes that the probability that tax noncompliance will be detected as revenue authorities across the globe strive to achieve high tax compliance levels. Indeed, Franzoni (2008) holds the same view that higher audit rates, may be the most important factor in encouraging tax compliance.

While a number of empirical studies relating to audit probability, detection and tax compliance do exist, their results seem to be mixed and unconvincing (Alm et al. 1992; Hashimzade, Myles, Page \& Rablen, 2014; Kahneman \& Tversky, 1979; Andreoni et al. 1998). For instance, Alm \& McKee (2006), report that there is a significant effect between tax audit probability and detection, and tax compliance among taxpayers, as cited in Alabede et al. (2011). Similarly, Bayer \& Cowell (2015) found a noteworthy positive association between tax audit probability and detection on firm tax compliance. Findings from these studies insinuate that when there is high possibility of the authorities discovering non-compliances, then compliance among tax payers would definitely improve (Alm 1991). In contrast, studies from Palil, Malek \& Jaguli (2016), Young (1994) and Slemrod, Blumenthal \& Christian (2001) reveal that the likelihood of detection adversely relates with tax compliance among taxpayers. This is demonstrated by Cummings, Martinez-Vazquez, McKee \& Torgler (2004) who indicate that increases in audit likelihood and penalty rates led to lower tax compliance among South African taxpayers. Conspicuously, there are no consistent results demonstrated by the existing scholarly works, however, audit 
probability and detection is anticipated to have an effect on taxpayers' compliance attitude and behaviour. 2.2.2 Sanctions and tax compliance

The Allingham \& Sandmo's (1972) deterrent model proposed the use of sanctions and audit probability to align non-compliant taxpayers with compliance behavior, since taxpayers are viewed as utility maximisers. Therefore, for the sake of seeing taxpayers desist from tax non-compliance behaviour, this framework incorporates sanctions as one of the dimensions of power in the model (Kirchler et al. 2008). Sanctions for tax non-compliance can be in terms of penalties, fine, interest, imprisonment and publications of names of non-complying taxpayers. The reviewed literature suggests that the size of the perceived penalties should be able to affect the likelihood of tax non-compliance (Varma \& Doob 1998; Raskolnikov 2009).

According to Raskolnikov (2009) a commitment to implementing government sanctions may not be the only way of encouraging taxpayers to pay taxes. Nonetheless getting commitment to an agreement with tax preparers to waive their privileges if they aid tax non-compliance, with tough standards and stronger sanctions for tax advisors could improve tax compliance. However, government could also implement a tax regime with a separation of taxpayers between the compliant and the non-compliant so that sanctions are placed on not more than one explicit group of taxpayers. Sanctions can be administered on taxpayers with a rational mind whose marginal compliance decisions largely depend on the expected tax penalty. This category of taxpayers is likely to choose the economic model given the costs that accrue (Raskolnikov 2009). If not differentiated, this methodology is likely to be wasteful when applied to taxpayers who are willing to pay their tax obligations and/or taxpayers who just need tax advice, respectful audits and campaigns for compliance (Raskolnikov 2009). Devos (2014), on the other hand, suggests a number of sanctions while emphasizing the need for the imposition of stronger penalties in response to the assertion that taxpayers weigh the uncertain benefits of successful evasion against the risk of detection and punishment. Despite recommending other areas for improvement (e.g. education, publicity, incentives), Devos (2015) contends that the punitive impact of penalties and other sanctions support the shaping of taxpayers' compliance positions and behaviour. Accordingly, a penalty structure forms part of the punishment and is an important feature of a taxpayer's decision to evade tax. This study seems to have been along the same line of thinking of that of Jackson \& Jones (1985), who supported government imposition of higher penalties due to increased tax non-compliance with the discovery that taxpayers were more sensitive to the magnitude of penalties than they were to probability of detection.

However, Jackson \& Milliron (1986) and Ameyaw, Oppong, Aba Abruquah \& Ashalley (2016), suggest that governments should take precautions when setting up policies relating to sanctions, as severe sanctions may not necessarily have a direct relationship with tax compliance. Other studies indicate that the social cost of sanctions could outweigh the benefits, as taxpayers may break up into smaller heterogeneous groups if sanctions are perceived as too severe, resulting in general aggression with disregard to tax legislation (Jackson \& Milliron 1986; Ameyaw et al. 2016). In fact, Graetz \& Wilde (1985), and Devos (2014) question the intrinsic worth of the economic theory of deterrence with the failure of penalties to improve tax compliance behavior. Hence, suggesting that governments need to employ a combination of factors, including auditing and reduced tax rates, so as to manage tax non-compliance. However, Blank (2014) proposes the use of collateral sanctions in addition to the customary or traditional monetary penalties, which would involve denying or withdrawal of government benefits in respect of perpetrators of tax non-compliance, the revocation of professional licences, and the deportation of those who propagate fraud and deceit in tax matters. Crawford (2013), on the other hand recognises the impact that effective penal provision can have in encouraging tax compliance. However, further notes that not all taxpayers deliberately set out to be tax non-compliant. As such, there are times, when unintentional errors and honest mistakes occur, probably resulting from taxpayers failing to understand the application of the law, with the implication that this category of taxpayers would possibly comply voluntarily if they had prior knowledge of the law (Saad 2010). The lack of information needed to comply, the costs involved in hiring technical staff like accountants and how long it takes for the tax officials to work on tax returns on submission may make it difficult for them to comply (Crawford 2013).

\subsubsection{Tax rate and tax compliance}

One of the factors that the economic theory of deterrence pronounces as a determinant of tax compliance is tax rate (Allingham \& Sandmo 1972). This theory predicts that an increase in tax rates would decrease tax compliance (Allingham \& Sandmo 1972), yet the available empirical studies provide diverse results about the effect of marginal tax rate on tax compliance. For instance, Clotfelter (1983), Feinstein (1991) and Slemrod (1985) show a positive relationship between marginal tax rate and tax non-compliance. This position is confirmed by FreireSeren \& Panades (2013) who argues that increases in tax rate reduce taxpayers' disposable incomes, leading to increased tax evasion, hence prompting an escalation in tax noncompliance. However, experiencing reductions in disposal incomes may cause increases in risk aversion, in turn enabling improvements in tax compliance behaviour. Consistent with these studies, Alm, Jackson \& McKee (1992b) suggest that the likelihood of under reporting of income is positively related to tax rate. Saavedra, Marcincin \& Valachy (1994), Ivanova, Keen \& Klemm (2005), and Saavedra, Marcincin \& Valachy (2007) however, argue for a flat tax rate, though such an opinion would to a 
great extent advantage the rich against the majority poor.

Baldry (1987) in an experimental investigation of the relationship between income, tax rates and tax evasion, designed particularly to test the predictions of the conventional expected-utility-maximisation analysis of evasion behavior, and found that, tax rate was insignificant, although income was positively related to evasion. Kirchler (2007) asserts that most economic models of rational compliance decisions do not clearly predict an effect of marginal tax rate on compliance nor hypothesise that higher tax rates lead to higher tax compliance. However, Kirchler (2007) suggests that most research shows that higher tax rates lead to less compliance. Nonetheless, Alm, Sanchez \& De-Juan (1995) show that, higher tax rates might indirectly increase tax compliance by reducing tax evasion. Moreover, Yitzhaki (1974) and Piolatto \& Rablen (2013) reveal that tax rates might have negative relationships with tax evasion, which implies that increases in tax rates might encourage taxpayers to truthfully declare their taxable incomes. However, rather than encouraging tax compliance through honesty, higher tax rates may serve as a disincentive to work by inducing the affluent to work for fewer hours, generating less wealth and fundamentally affecting the efficiency of the economy (Kirchler 2007), hence negatively affect tax compliance (Chau \& Leung 2009; Mas'ud, Aliyu \& Gambo 2014). In conclusion, though various studies conceived that higher tax rate is negatively related to tax evasion and positively related to tax compliance, other studies reveal either no relationship or negative relationship between tax rates and tax compliance. Based on this, Gaspar (2015) suggests that the theory has ambiguities in its formulation and therefore, further research is needed in this area (Freire-Seren \& Panades 2013).

The reviewed empirical results show that the deterrent or economic factors, namely audit probability and detection, sanctions in form of penalties and fines tax rate, are not consistent in predicting tax compliance behaviour. Some of the findings showed that these dimensions can encourage tax compliance behaviour, whereas others indicate that higher sanctions could lead to increased tax avoidance and evasion or have no influence on tax compliance behaviour. Due to the inconsistency in the relationship between deterrent factors and tax compliance among different taxpayers, the current study proposes the following:

H1. Deterrent factors and tax compliance are significantly related.

2.2.4 Tax complexity and tax compliance

Complexity does arise when the relevant tax authorities try to improve the equity of the tax system and, at the same time, reduce its ambiguity (McKerchar, Ingraham \& Karlinsky 2005). Therefore, findings regarding this construct appeared to be mixed in the literature. In particular, McKerchar (2003) claimed that, both monetary and non-monetary cost may be influenced by a corresponding increase in complexity, thereby causing a negative impact on the taxpayers' perception of fairness, as well as their respective commitment to comply.

To reiterate further, Cox \& Eger (2006) who focused on the State Road Funds in the US State of Kentucky claimed that procedural tax complexity contributes to an increase in tax noncompliance. In the same vein, Gambo, Mas'ud, Nasidi \& Oyewole (2014) who studied the relationship between tax complexity and tax compliance in Africa under the self-assessment regime discovered a statistically significant negative relationship between tax complexity and tax compliance. Conversely, Kirchler, Niemirowski \& Wearing (2006) found a positive relationship between tax complexity and tax compliance. Meanwhile, Forest \& Sheffrin (2002) failed to discover the influence of complexity on taxpayers' perception towards fairness and compliance. Aligning to equity theory, Fjeldstad, Sjursen \& Ali (2012) stated that when the tax system is perceived to be complex, taxpayers may stand to question its fairness. As such, the more complex a tax system is, the more taxpayers perceive the inequity of the whole system. Thus, based on the theoretical justification, tax complexity may portray some level of negativity on tax compliance behaviour. As a result, when the tax system is found to be complex or cumbersome, taxpayers may perceive the lack of equity in the system which may result in low compliance. Hence, the following proposition is offered:

H2: There is a significant negative relationship between tax complexity and tax compliance behaviour.

\subsection{Social psychological factors and tax compliance}

\subsubsection{Tax fairness perceptions and tax compliance}

Fairness is a perception; an imagination that involves an evaluation as a result of comparing one's own situations or those of oneself and others (Van den Bos, Peters, Bobocel \& Ybema 2006). Similarly, Farrar, Donnelly \& Dhaliwal (2013) argue that fairness is a judgment of individuals, and individuals with referent others arising from actual or abstract appraisals, which has significant ethical consequences. This means that where individuals hold perceptions of fairness, they will develop a sense of contentment and will tend to support such a fair tax system. However, individuals are likely to experience anger and have negative reactions when they perceive violations of fairness (Schweitzer \& Gibson 2008). In particular, SME taxpayers are likely to be more compliant when they perceive fairness of a tax system and less compliant when they perceive unfairness in such a tax system (Slemrod 2007). Therefore, an attempt to develop a broader understanding of tax fairness could be helpful to tax authorities, as they might be able to use fairness as one of the compliance approaches to enhance and raise taxpayers' spirits with regard to compliance behaviour (Farrar, et al. 2013). 
According to equity theory, Bobek (1997) in Saad (2011), suggests that outcomes like services provided determine peoples' perceptions of system fairness, and they consequently trust that incentives and punishments will be spread according to the inputs or contributions. By implication, this theory highlights exchange fairness, where it suggests that individuals are more likely to conform to the tax rules if the procedures used in the exchange contract are perceived to be fair. In the tax environment, the taxpayers and government are the parties that form the exchange contract. Taxpayers will notionally perceive the tax system as fair if the government is seen to be providing equitable proportions of benefits, such as social services, hence encouraging tax compliance otherwise it might trigger tax noncompliance if considered unfair (Saad 2011).

Tax fairness is considered in three elements; distributive fairness, procedural fairness and retributive fairness. Distributive fairness considers the allocation function where government apportions public funds collected for the benefit of society (Adams 1965). Additionally, people perceiving fairness in the perspective of the benefits they receive will also compare their situations with their referent others, equating their benefits-contribution ratios with those of others in the group, and feelings of inequitable dealings can be revealed if disparities are discovered (Saad 2011; Walster et al. 1978). Based on this principle, the theory of distributive justice assumes that people with comparable contributions should get equal distribution outcomes (Huseman, Hatfield \& Miles 1987). Although the principle of exchange fairness gives prominence to the allocation of resources and rewards in exchange for taxes paid, there are situations in which the principle is not followed in the actual allocation of rewards (Greenberg 1987; Schwinger 1980). On the other hand, though distributive fairness denotes fairness of tax revenue allocation, it might also refer to the allocation of a tax burden among taxpayers, and once perceived as fair, taxpayers will be encouraged to compliance with tax rules.

Distributive justice refers to the fairness of the outcomes of resource allocation or distribution (Wenzel 2003). The theory looks at how taxpayers judge fairness in the distribution of outcomes. Therefore, under distributive fairness, the perception is that the government acts as a good custodian and wise spender of tax revenues (OECD 2011). In Verboon \& Goslinga's (2009) assertion, typical benefits are the share of public goods one receives and the most important costs are the actual taxes that have to be paid. This would imply that taxpayers would be motivated to comply with the tax law if they perceive the government to be providing adequate services as a proportion of the tax revenue (Walster, et al. 1978; Gravelle \& Gravelle 2006; Kirchler et al. 2006). Looking at retributive fairness, the negative aspect of distributive fairness, we study fair allocation of punishments (Cook \& Hegtvedt 1983). Punishments are considered fair if the penalties enforced are commensurate with the offenses committed. In tax environments, various punishments are available as penalties for non-compliance behaviour. Therefore, retributive fairness contends that a tax system should be in a position to be able to employ such penalties in proportion to the level of non-compliance behaviour.

On the other hand, Murphy (2004) considers procedural fairness as perceived fairness of the procedures used in decision-making and how this action is perceived by the receiver of the decision maker's treatment. Procedural fairness, also called process fairness, involves the study of mechanisms aimed at implementing the fairness principles for decision making (Fuller 1961; Greenberg 1987; Konow 2003). Normally, if a tax system is to be viewed as procedurally fair, it ought to fit into the six principles against which fairness of procedures is measured (Leventhal 1980). According to Leventhal (1980), procedural fairness, government procedures need to be consistent, without bias, accurate, with the ability to be corrected, representative and encourage ethical behaviour. non-violation of these measures would encourage tax compliance behaviour among taxpayers as procedures would be perceived as fair (Leventhal, Karuza \& Fry 1980). Barret-Howard \& Tyler (1986) and Greenberg (1987) suggested consistency as the most powerful criterion for procedural fairness. This means that setting out fair procedures within the tax system for the tax identification, registration, assessment and tax collection could stimulate taxpayers' perceptions of fairness in such a system and tax compliance. Once the procedures employed in the assessment and collection of taxes are viewed as unfair, high non-compliance inclinations may result. If they are not, compliance may be experienced. According to Saad (2011), taxpayers will ordinarily assess the consistency of the application of procedures within the tax system when developing their fairness conclusions, with the expectation that the application is consistent over time and across taxpayers. Bias suppression is another significant characteristic of fairness procedures and asserts that no partisan or selfish treatment should be promoted in the application of tax system procedures. Besides, tax system procedures should promote accuracy to create perceptions of fairness when taxpayers make decisions based on the available information. The system should also provide for flexibility, so that taxpayers are able to make adjustments for any incorrect decisions made, to fulfil the requirements of the correctability measure.

2.3.2 Trust in authorities and tax compliance

Trust in authorities implies that taxpayers and social groups believe that the tax authorities are benevolent and work for the common good of society (Kirchler et al. 2008; Kogler et al. 2013). Trust in authorities markedly has its prominence from perceptions of tax fairness, a target for every economy in order to boost tax compliance (Bobek 1997). Indeed, taxpayers will be able to trust the government and tax authorities if the allocation and allocative procedures as well as tax administration procedures are perceived as appropriate. For instance, trust will 
be developed if governments use public resources to reduce the gaps that may exist between the rich and poor through the provision of goods and services that would probably not be provided efficiently by the private sector. It may also mean that taxpayers who earn less may not be taxed in the same way as the rich (Jackson \& Milliron 1986; Saad 2010), which can be interpreted as equal treatment of all taxpayers who are at similar income levels (Niesiobedzka 2014).

According to Kornhauser (2007) and identification with a group or society might change individuals' positioning of self-interest to collective orientation, focusing majorly on what fits for the group members as a whole creating the basis of trust. Trustworthy engagements by government engender social trust by instituting a shared identity or social bond (Braithwaite 1995). Therefore, the social norm of trust held by that group can form the societal foundation in the perceptions of trustworthy arrangements by government. Additionally, Wenzel (2004) finds that social norms have a significant effect when identification with the group of people to whom the norms are attributed is sturdier. If trust is then considered as a social norm, then the social norm of trust will be strengthened with the stronger identity with the social group. Indeed, the notion of trust as a social norm has been confirmed by Ben-Ner \& Halldorsson (2010), Ashraf, Bohnet \& Plankov (2006), and Castelfranchi \& Falcone (2001). As Wenzel (2002) demonstrates, procedural fairness of the tax authorities might be mostly influential in motivating tax compliance among citizens who strongly identify with the notion of trust. Also, at a higher level, tax authorities might be perceived as archetypal of taxpayers when they exemplify the principles and standards of trustworthiness, fairness, neutrality (Bornman 2015). This means that taxpayers' identification with authorities might lead to perception of authorities to be more legitimate, fair and trustworthy (Taylor 2002) which can enhance tax compliance (Bobek, Hageman \& Kelliher 2015; Bobek, Hageman \& Kelliher 2012).

Kirchler, Hofmann \& Gangl (2012) make a distinction between reason-based trust and implicit trust as the two merits of trust, resulting from Castelfranchi and Falcone's work. Trust as a mental attitude can either be goalbased or belief-based (Castelfranchi \& Falcone 2010; Kirchler et al. 2012). Reason-based trust rests upon a rational decision to trust another person based on whether the trustee and trustor have the same goals, which is akin to procedural fairness. However, implicit trust is a reflex and emotional reaction derived from social relationships that ensue between people, and conditioned learning processes and memory that is similar to legitimacy and identity (Bornman 2015). Whether reason-based trust or implicit trust, the ultimate result is likely to be higher motivation for the taxpayers like SMEs to comply with the requirements of the tax rules. Again, one would wonder whether trust in the general government influence trust in tax authority particularly in circumstances where people feel the presence of high corrupt and wasteful practices in government. Yet it's believed that trust would be most needed where significant conflicts of interest exists (Balliet, Mulder \& Van Lange 2011). This might actually provide a signal that corruption might have an influence on the relationship between social psychological factors and tax compliance of SMEs in Uganda. From this discussion, we propose that:

H3. Social psychological factors have a significant relationship with tax compliance.

\subsection{Perceived corruption as Potential Moderator}

Significant evidence on how the economic and social psychological factors affect tax compliance behaviour continue to be inconsistent and inadequate. Several studies for example reveal wide-ranging findings of the effects of audit probability and detection on tax compliance (Stefura 2012; Palil \& Mustapha 2011; Cummings et al. 2004; Kirchler 2007; Alm et al. 2004; Slemrod et al. 2001; Allingham \& Sandmo 1972) and the effects of tax rates on tax compliance (e.g. Chau \& Leung 2009; Barbuta-Misu 2011; Pommerehne \& Weck-Hannemann 1996; Alm et al. 1992; Feinstein 1991; Porcano 1988; Clotfelter 1983; Allingham \& Sandmo 1972). Mixed findings have also been revealed regarding the effect of tax complexity on tax compliance (Saad 2014; Sawyer 2007; McKerchar 2003; Forest \& Sheffrin 2002). Similar inconsistent results have been reported for tax fairness to the extent that self-reported past evaders even perceived the tax system as fairer than non-evaders (Porcano 1988). Similarly, numerous studies have examined the effects of distributive fairness on tax compliance however, their findings remain mixed (Wenzel 2002).

With the inconsistency in the results that the existing studies report as regards the relationship between economic factors and social psychological factors on tax compliance, it may appear that an introduction of a moderator as has been recommended in the extant literature (Baron \& Kenny 1986). While Picur \& Riahi-Belkaoui (2006) provide a discussion on the effects of noneconomic factors like perceptions of corruption and other related features, they affirm that these factors could actually moderate the effects of deterrent and social psychological constructs on tax compliance. Furthermore, Rahmani, Komijani \& Fallahi (2012) argue that when a country has minimal incidences of corruption, tax compliance is likely to improve as taxpayers might develop the willingness to pay taxes. This would generally imply that high corruption perceptions like petty corruption, petty tax corruption, political corruption and grand corruption might negatively influence the willingness to pay taxes, hence tax noncompliance. Bringing this in line with the social exchange theory, trust is built on social interactions and can only be sustained if these relationships are beneficial to the parties involved (Diekmann, Jann, Przepiorka \& Wehrlia 2014; Serva, Fuller \& Mayer 2005; Blau 1964). Consequently, when taxpayers notice the government is 
corrupt, meaning that not all the taxes paid are put to good use in the provision of public goods and services, then taxpayers might feel like they are being cheated which may as a consequence affect their tax compliance potential. Henceforth, in this study we suggest that perceptions of corruption (i.e. petty corruption, petty tax corruption, political corruption and grand corruption) might significantly make a contribution in appreciating the inconsistencies in the existing results regarding the relationships between both the deterrent factors (e.g. audit probability and detection, sanctions, tax rates and tax complexity) and social psychological factors (tax fairness, trust in authorities) on tax compliance. Additionally, we argue that the strength of the relationships between deterrent factors and social psychological factors on tax compliance might be affected if the tax system is perceived as unfair.

Considering our preceding discussions of prior results and theory, we can rationally argue that the level of the perceptions of corruption might influence the tax compliance behaviour of taxpayers irrespective of how the tax system is perceived as fair or the trustworthiness of the tax authorities and how strong the deterrent factors (like detection rates, sanctions with high tax rates) are believed to be. Moreover, little is known about the moderating effects of the perceptions of corruption on the relationships between deterrent factors and social psychological factors on tax compliance behaviour, notwithstanding the rationalization for the foregoing proposition. In principle, the two drivers of tax compliance namely social psychological factors and deterrent factors might be inadequate in offering the explanation for tax compliance the puzzle, a combination of both deterrent and a social psychological factors blended with perceptions of corruption as a moderator might be used to offer a judicious clarification to the tax compliance puzzle. Consequently, we offer the following proposal:

H4: perceptions of corruption can moderate the effect of the relationships between deterrent factors and social psychological factors on tax compliance.

\section{Conceptualised framework}

This proposed conceptual framework as represented in Figure 1 below builds on the foregoing inconsistencies in the empirical results describing the relationships between deterrent and social psychological factors on tax compliance as an impending research problem. The central objective of this scholarship thus is to offer proposition regarding the moderating role of the perceptions of corruption on the relationships between deterrent and social psychological factors on tax compliance behaviour of the owners and managers small and medium enterprises in Uganda.

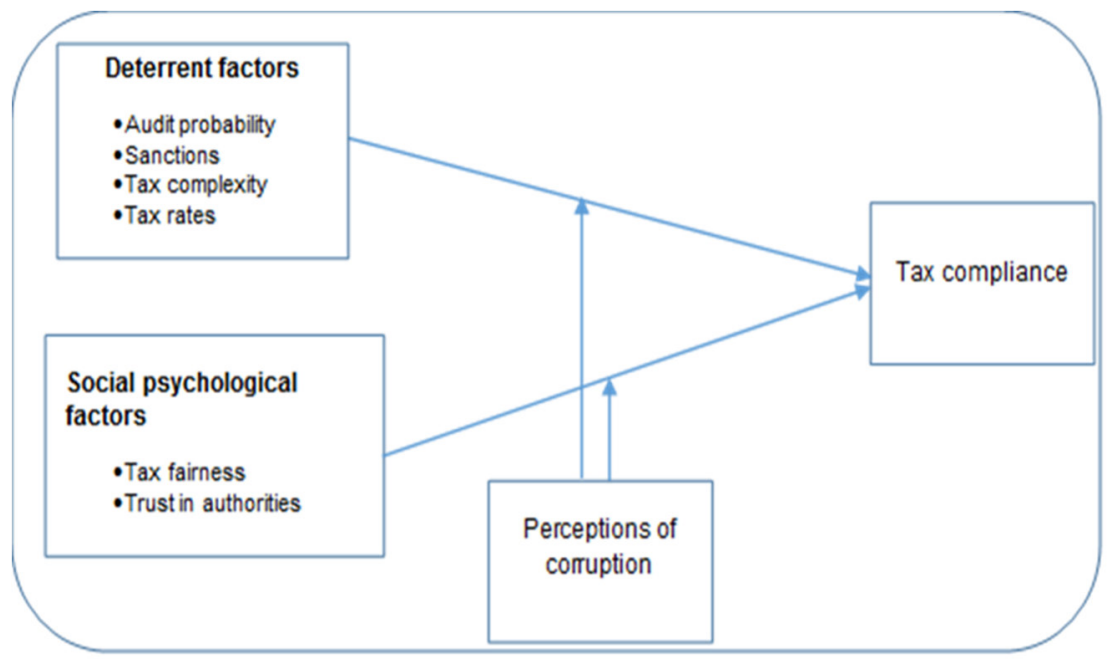

Figure 1. Proposed conceptual framework

Figure 1 proposes a conceptual framework which demonstrates the moderating role of perceptions of corruption of the relationships that exist between the deterrent factors (audit probability and detection, sanctions, tax complexity and tax rates) and social psychological factors (tax fairness and trust in authorities) on tax compliance. Social psychological factors as well as deterrent factor might have significant effects on tax compliance of SME taxpayers as has been demonstrated by the existing scholarship. Though the social psychological factors like tax fairness and trust in authorities have been introduced given the suggestion that deterrent factors are inadequate in motivating tax compliance among taxpayers, compliance has still remained low among SMEs in developing countries like Uganda which is a puzzle. Therefore, the introduction of an additional social psychological factor in the perceptions of corruption in the two models could support in providing an explanation of the tax compliance behaviour of the SME owners and managers which might be due to the distortions in public provision arising from perceptions of corruption. Existence of the perceptions of corruption might affect the probability of tax compliance if they are preceded by the public provision distortions. 


\section{Conclusion}

In this study, we propose a model depicting the potential moderating influence of the perceptions of corruption on the relationships that exist between deterrent and social psychological factors and tax compliance behaviour as Figure 1 demonstrates. We believe that this model reveals significant implications which might support in understanding which factors could affect the tax compliance behaviour of SME owners and managers, which might be of greater importance generally. First of all, the framing of this study infers the fact that positivist approach might be used in future researches if the conceptual framework presented in this study is authenticated. This means that a quantitative approach will be adopted in data collection, analysis and reporting of results. These results are likely to provide significant insights to academics, policy makers at Ministry of Finance, policy implementers at Uganda Revenue Authority, and practitioners. Second, the findings in utilising this model might as well bring insights to the Government of Uganda on the possibilities of reducing the effects of the perceptions of corruption so as to achieve public revenue sustainability.

\section{References}

Alleyne, P. \& Harris, T. (2017), “Article information: Antecedents of Taxpayers' Intentions to Engage in Tax Evasion: Evidence from Barbados Abstract Purpose".

Allingham, M. \& Sandmo, A. (1972), "Income Tax Evasion - A Theoretical Analysis", Journal of Public Economics 1(FEBRUARY 1974), 323-338.

Alm, J., Martinez-Vazquez, J. \& McClellan, C. (2016), “Corruption and Firm Tax Evasion”, Journal of Economic Behavior and Organization, 124, Elsevier, 146-163.

Alm, J. (1991), "A Perspective on the Experimental Analysis of Taxpayer Reporting", The Accounting Review, 66(3), 577-593

Alm, J., Jackson, B. R. \& Mckee, M. (1992), "Estimating the Determinants of Taxpayer Compliance with Experimental Data", National Tax Journal, 45(1), 107-114.

Alm, J. \& McKee, M. (2006), “Audit Certainty, Audit Productivity, and Taxpayer Compliance”, National Tax Journal, 59(4), 801-816.

Alm, J., Sanchez, I. \& De Juan, A. (1995), "Economic and Noneconomic Factors in Tax Compliance”, Kyklos, 48(1), 1-18 June 1994.

Ameyaw, B., Oppong, A., Aba Abruquah, L. \& Ashalley, E. (2016), "Informal Sector Tax Compliance Issues and the Causality Nexus between Taxation and Economic Growth: Empirical Evidence from Ghana", Modern Economy, 07(12), 1478-1497.

Ashraf, N., Bohnet, I. \& Piankov, N. (2006), “Decomposing Trust and Trustworthiness", Exp Econ, 9, $193-208$.

Baldry, C. J. (1987), "Income Tax Evasion and the Tax Schedule: Some Experimental Results", Public Finance, 42(3), 357-383.

Balliet, D., Mulder, L. B. \& Van Lange, P. A. M. (2011), "Reward, Punishment, and Cooperation: A MetaAnalysis", Psychological Bulletin, 137(4), 594-615.

Bărbuţămişu, N. (2011), "A Review of Factors for Tax Compliance. Annals of "Dunarea de Jos", University of Galati, Economics and Applied Informatics, EAI, 69-76.

Baron, R. M. \& Kenny, D. A. (1986), "The Moderator-Mediator Variable Distinction in Social Psychological Research: Conceptual, Strategic, and Statistical Considerations”, Journal of Personality and Social Psychology, 51(6), 1173-1182.

Barret-Howard, E. \& Tyler, T. R. (1986), "Procedural Justice as A Criterion in Allocation Decisions", Journal of Personality and Social Psychology, 50(2), 296-304.

Bayer, R. \& Cowell, F. (2016), “Tax Compliance by Firms and Audit Policy”, Research in Economics, 70(1), 3852.

Becker, G. S. (1974), “Crime and Punishment: An Economic Approach”, University of Chicago and National Bureau of Economic Research, 1-54.

Ben-ner, A. \& Halldorsson, F. (2010), "Trusting and Trustworthiness: What are They, How to Measure Them, and What Affects Them", Journal of Economic Psychology, 31(1), 64-79.

Blank, D. J. (2016), “Collateral Compliance”, University of Pennsylvania Law Review, 162(4), 719-800.

Blau, P. M. (1964), "Exchange and Power in Social Life", New York: Wiley.

Bobek, D. D., Hageman, A. M. \& Kelliher, C. F. (2013). “Analyzing the Role of Social Norms in Tax Compliance Behavior", Journal of Business Ethics, 115(3), 451-468.

Bosco, L. \& Mittone, L. (1997), "Tax Evasion and Moral Constraints: Some Experimental Evidence", Kyklos, 50(3), 297-324.

Braithwaite, V. (1995), "Games of Engagement: Postures Within the Regulatory Community", Law \& Policy, 17(3), 225-255.

Braithwaite, V. (2009), "Defiance in Taxation and Governance: Resisting and Dismissing Authority in A Democracy”, Edward Elgar, Chetenham. 
Braithwaite, V. (2009), “Tax Evasion. In M. Tonry. Handbook on Crime and Public Policy”, Oxford: Oxford University Press.

Bruce-Twum, E. (2014), "Gift Tax Compliance in Ghana, an Empirical Study". Journal of Finance and Accounting, 2(1), 1-7.

Carnes, G. A. \& Englebrecht, T. D. (Spring 1995), “An Investigation of the Effect of Detection Risk Perceptions, Penalty Sanctions, and Income Visibility on Tax Compliance", The Journal of the American Taxation Association; Sarasota, 17(1), 26.

Castelfranchi, C. \& Falcone, R. (2001), "Social Trust: A Cognitive Approach", National Research Council Institute of Psychology, Roma - Italy.

Chau, G. \& Leung, P. (2009), "A Critical Review of Fischer Tax Compliance Model: A Research Synthesis", Journal of Accounting and Taxation, 1(2), 34-40.

Clotfelter, T. C. (1983), "Tax Evasion and Tax Rates: An Analysis of Individual Returns", The Review of Economics and Statistics, 65(3), 363-373.

Cook, K. S. \& Hegtvedt, K. A. (1983), "Distributive Justice, Equity and Equality", Annual Review Inc., 9, $217-$ 241.

Cox, S. P. \& Eger, R. J. (2006). Procedural complexity of tax administration: The road fund case. Journal of Public Budgeting, Accounting \& Financial Management, 18(3), 259-283.

Crawford, D. (2013), "Filing and Payment: Detailed Guidelines for Improved Tax Administration in Latin America and The Caribbean", USAID Leadership in Public Financial Management, 4-61.

Cummings, R. C., Martinez-Vazquez, J., McKee, M. \& Torgler, B. (2004), "Effects of Culture on Tax Compliance: A Cross Check of Experimental and Survey Evidence", CREMA working Paper No. 2004-13.

Dare, C., du Plessis, S. \& Jansen, A. (2019), “Tax Revenue Mobilisation: Estimates of South Africa's Personal Income Tax Gap", South African Journal of Economic and Management Sciences, 22(1), 1-8.

Devos, K. (2014). "Do Penalties and Enforcement Measures Make Taxpayers More Compliant?-The View of Australian Tax Evaders", Journal of Business and Economics, 5(2), 265-284.

Diekmann, A., Jann, B., Przepiorka, W. \& Wehrlia S. (2014), "Reputation Formation and The Evolution of Cooperation in Anonymous Online Markets", American Sociological Review, 79(1), 65-85.

Dwenger, N., Kleven, H., Rasul, I. \& Rincke, J. (2016), "Extrinsic and Intrinsic Motivations for Tax Compliance: Evidence from A Field Experiment in Germany". American Economic Journal: Economic Policy, 8(3), 203232.

Faizal, S. M., Palil, M. R., Maelah, R. \& Ramli, R. (2017), "Perception on Justice, Trust and Tax Compliance Behavior in Malaysia", Kasetsart Journal of Social Sciences, 38(3), 226-232.

Farrar, J. M., Donnelly, M. E. \& Dhaliwal, S. B. (2013), "Procedural Aspects of Tax Fairness: A Content Analysis of Canadian Tax Jurisprudence", The ATA Journal of Legal Tax Research, 11(2), 21-37.

Franzoni, L. A. (2000), “Tax Evasion and Tax Compliance”, Encyclopedia of Law and Economics, VI, 52-94.

Franzoni, L. A. (2008), “Tax compliance Encyclopedia of Law and Economics”, (July), 1-31.

Feinstein, S. J. (1991), “An Econometric Analysis of Income Tax Evasion”, RAND Journal of Economics, 22(1), 14-35.

Fischer, C. M., Wartick, M. \& Mark, M. M. (1992), "Detection Probability and Taxpayer Compliance: A Review of the Literature", Journal of Accounting Literature; Gainesville, 11, 1.

Fjeldstad, O., Schulz-Herzenberg, C. \& Sjursen, H. I. (2012), "Peoples' Views of Taxation in Africa: A Review of Research on Determinants of Tax Compliance", CMI Working Paper WP 2012:7.

Forest, A. \& Sheffrin, M. S. (2002), "Complexity and Compliance: An Empirical Investigation", National Tax Journal, LV(1), 75-88.

Freire-serén, M. J. \& Panadés, J. (2013), “Do Higher Tax Rates Encourage / Discourage Tax Compliance?”, Modern Economy, 4, 809-817.

Fuller, L. (1961), “The adversary system, In H. Berman (Ed.), Talks on American Law (10-22)”, New York: Vintage Books.

Gambo, E. J., Nasidi, M. \& Oyewole, O. S. (2014), "Tax Complexity and Tax Compliance In African SelfAssessment Environment", International Journal of Management Research \& Review, 4(5), 575-582.

Gaspar, V. (2015), "Current Challenges in Revenue Mobilization: Improving Tax Compliance", International Monetary Fund, Washington DC.

Geibart, N. (2014), "Digging Out the Complexities of Tax Compliance”, The Business, 32-33.

Graetz, M. J. \& Wilde, L. L. (1985), “The Economics of Tax Compliance: Fact and Fantasy”, National Tax Journal, 38(3), 355-363.

Gravelle, J. \& Gravelle, J. (2006), "Horizontal Equity and Family Tax Treatment: The Orphan Child of Tax Policy", National Tax Journal, LIX(3), 631-649.

Greenberg, J. (1987), “Taxonomy of Organizational Justice Theories”, Academy of Management Review, 12(1), $9-22$. 
Huseman, R.C., Hatfield, J.D. \& Miles, E.W. (1987), “A New Perspective on Equity Theory: The Equity Sensitivity Construct", Academy of Management Review, 12(2), 222-234.

Iftikhar, M., Husnain, U., Haider, A., Ul, I., Padda, H. \& Khan, M. (2015), "Public Expenditure, Taxes and Economic Development: An Empirical Analysis for Pakistan", Middle-East Journal of Scientific Research, 23(11), 2756-2762.

Ivanova, A., Keen, M. \& Klemm, A. (2005), “The Russian Flat Tax Reform”, IMF Working Paper, WP/05/16.

Jackson, B. \& Milliron, V. (1986), “Tax Compliance Research: Findings, Problems and Prospects”, Journal of Accounting Literature, 5, 125-165.

James, S. \& Alley, C. (2009), "Tax Compliance, Self-Assessment and Tax Administration School of Business and Economics, University of Exeter. Journal of Finance and Management in Public Services, 2(2), 27-42.

Kastlunger, B., Lozza, E., Kirchler, E. \& Schabmann, A. (2013), "Powerful Authorities and Trusting Citizens: The Slippery Slope Framework and Tax Compliance in Italy", Journal of Economic Psychology, 34, 36-45.

Kirchler, E. (2007), "The Economic Psychology of Tax Behavior", Cambridge, U.K.: Cambridge University Press.

Kirchler, E., Hoelzl, E. \& Wahl, I. (2008), "Enforced Versus Voluntary Tax Compliance: The "Slippery Slope" Framework", Journal of Economic Psychology, 29(2), 210-225.

Kirchler, E., Niemirowski, A. \& Wearing, A. (2006), "Shared Subjective Views, Intent to Cooperate and Tax Compliance: Similarities Between Australian Taxpayers and Tax Officers", Journal of Economic Psychology, 27(4), 502-517.

Schwab, K. (2016), “The Global Competitiveness Report 2016-2017”, World Economic Forum.

Kogler, C., Muehlbacher, S. \& Kirchler, E. (2013), "Trust, Power and Tax Compliance: Testing the "Slippery Slope Framework" Among Self-Employed Taxpayers. SSRN Electronic Journal.

Konow, J. (2003), "Which is the Fairest One of All? A Positive Analysis of Justice Theories", Journal of Economic Literature, 41(4), 1188-1239.

Kornhauser, M. E. (2007), "Normative and Cognitive Aspects of Tax Compliance: Literature Review and Recommendations for The IRS Regarding Individual Taxpayers", 2007 Annual Report to Congress, 138-180.

Leventhal, G. S. (1980), "What Should Be Done with Equity Theory? New Approaches to The Study of Fairness in Social Relationships", In: M. K. Gergen, J. Greenberg, \& R. Willis, 'Social Exchange: Advances in Theory and Research, 27-55. New York, NY: Plenum Press.

Leventhal, G. S., Karuza, J. \& Fry, W. R. (1980), "Beyond Fairness: A Theory of Allocation Preferences", In: Mikula, G., Ed., Justice and Social Interaction, Springer-Verlag, New York, 167-218.

Mas'ud, A., Aliyu, A. A. \& Gambo, J. E. (2014), “Tax Rate and Tax Compliance in Africa”, European Journal of Accounting Auditing and Finance Research, 2(3), 22-30.

Mckerchar, B. M., Ingraham, L. R. \& Karlinsky, S. (2005), "Tax Complexity and Small Business: A Comparison of the Perceptions of Tax Agents in The United States and Australia", Journal of Australian Taxation, 8(2), 289-327.

McKerchar, M. (2003), "The Study of Income Tax Complexity and Unintentional Noncompliance: Research Method and Preliminary Findings", ATAX Discussion Paper Series No 6. from SSRN Electronic Journal.

Muehlbacher, S. \& Kirchler, E. (2010), "Tax Compliance by Trust and Power of Authorities. International Economic Journal, 24(4), 607-610.

Murphy, T. (2001), "When Compliance Is Not The Solution But The Problem: From Changes In Law To Changes In Attitude", Working paper No. 18.

Murphy, K. (2004), "Moving Towards a More Effective Model of Regulatory Enforcement in the Australian Taxation Office, Centre for Tax System Integrity”, Research School of Social Sciences, Australian National University 2004, Working Paper No. 45.

Musimenta, D., Nkundabanyanga, S. K., Muhwezi, M., Akankunda, B. \& Nalukenge, I. (2017), "Tax compliance of small and medium enterprises: A developing country perspective", Journal of Financial Regulation and Compliance, 25(2), 149-175.

Niesiobedzka, M. (2014), "Typology of Taxpayers and Tax Policy", Polish Psychological Bulletin, 45(3), 372379.

Nkundabanyanga, S. K., Mvura, P., Nyamuyonjo, D., Opiso, J., \& Nakabuye, Z. (2017), “Tax Compliance in A Developing Country: Understanding Taxpayers' Compliance Decision by Their Perceptions", Journal of Economic Studies, 44(6), 931-957.

Nkwe, N. (2012), “Tax Payers' Attitude and Compliance Behavior among Small Medium Enterprises (SMEs) in Botswana", Business and Management Horizons, 1(1), 113-137.

OECD (2001), "Citizens as Partners: OECD Handbook On Information, Consultation and Public Participation in Policy-Making".

OECD (2004). "Compliance Risk Management: Managing and Improving Tax Compliance October 2004".

OECD (2011), "Tax Administration in OECD and Selected Non-OECD Countries: Comparative Information Series (2010)", Forum on Tax Administration. 
OECD. (2018), "Tax Transparency in Africa, Africa Initiative Progress Report, 1-49.

Palil, M. R., Malek, M. M. \& Jaguli, A. R. (2016), "Issues, Challenges and Problems with Tax Evasion: The Institutional Factors Approach". Gadjah Mada International Journal of Business, 18(2), 187-206.

Palil, M. R. \& Mustapha, A. F. (2011), Factors Affecting Tax Compliance Behaviour in Self-Assessment System", African Journal of Business Management, 5(33), 12864-12872.

Picur, R. D. \& Riahi-Belkaoui, A. (2006), "The Impact of Bureaucracy, Corruption and Tax Compliance", Review of Accounting and Finance, 5(2), 174-180.

Piolatto, A. \& Rablen, D. M. (2013), "Prospect Theory and Tax Evasion: A Reconsideration of the Yitzhaki Puzzle", Institute for Fiscal Studies, Working Paper W13/25.

Pommerehne, W. W. \& Weck-Hannemann, H. (1996), "Tax Rates, Tax Administration and Income Tax Evasion in Switzerland", Public Choice, 88(1/2), 161-170.

Porcano, T. M. (1988), “Correlates of Tax Evasion”, Journal of Economic Psychology, 9(1), 47-67.

Rahmani, T, Komijani, A. \& Fallahi S. (2012), "An Examination of the Relationship Between Corruption and Inflation Tax: A Cross-Country Study”, taxjournal. 2012; 20(13), 45-70.

Raskolnikov, A. (2009), "Revealing Choices: Using Taxpayer Choice to Target Tax Enforcement", Columbia Law Review, 109(4), 689-754.

Ronald D. Picur, D. R. \& Riahi-Belkaoui, A. (2006), "The Impact of Bureaucracy, Corruption and Tax Compliance", Review of Accounting and Finance, 5(2), 174-180.

Rosid, A., Evans, C. \& Tran-Nam, B. (2016), "Do Perceptions of Corruption Influence Personal Income Taxpayer Reporting Behaviour? Evidence from Indonesia", eJournal of Tax Research, 14(2), 387- 425.

Roth, J. A., Scholz, J. T. \& Dry-Witte, J. T. (1989), "Taxpayer Compliance: An Agenda for Research", Philadelphia, University of Pennsylvania Press.

Saad, N. (2010), "Fairness Perceptions and Compliance Behaviour: The Case of Salaried Taxpayers in Malaysia After Implementation of the Self-Assessment System. eJournal of Tax Research, 8(1), 32-63.

Saad, N. (2011), "Fairness perceptions and compliance behaviour: Taxpayers' judgments in self-assessment environments", PhD Thesis, University of New South Wales, Australia.

Saad, N., Udin, N. M. \& Derashid, C. (2014), "Complexity of the Malaysian Income Tax Act 1967: Readability Assessment”, Procedia - Social and Behavioral Sciences, 164(August), 606-612.

Saad, N. (2014), "Tax Knowledge, Tax Complexity and Tax Compliance: Taxpayers' View. Procedia - Social and Behavioral Sciences, 109(1), 1069-1075.

Saavedra, P., Marcincin, A. \& Valachy, J. (2007), "Flat Income Tax Reforms", Fiscal Policy and Economic Growth.

Sawyer, A (2007), New Zealand's tax rewrite programme: In pursuit of the (Elusive) goal of simplicity. British Tax Review, 4, 405-427.

Schneider, F. \& Torgler, B. (2007), "Shadow Economy, Tax Morale, Governance and Institutional Quality: A Panel Analysis”, Working Paper, No. 0701, Johannes Kepler University of Linz, Department of Economics, Linz.

Schweitzer, M. \& Gibson, D. E. (2008), "Fairness, Feelings, and Ethical Decision Making: Consequences of Violating Community Standards of Fairness", Journal of Business Ethics, 77(3), 287-301.

Schwinger, T. (1980), "Just Allocation of Goods: Decisions Among Three Principles", In G. Mikula (Ed.), Justice and Social Interaction, 95-125. New York: Springer-Verlag.

Serva, A. M., Fuller, A. M. \& Mayer, C. R. (2005), "The Reciprocal Nature of Trust: A Longitudinal Study of Interacting Teams", Journal of Organizational Behavior. 26, 625-648.

Slemrod, J. (1985), “An Empirical Test for Tax Evasion”, The Review of Economics and Statistics, 67(2), 232238

Slemrod, J. (2007), "Cheating Ourselves: The economics of Tax Evasion. Journal of Economic Perspectives, 21(1), $25-48$.

Slemrod, J., Blumenthal, M. \& Christian, C. (2001), "Taxpayer Response to an Increased Probability of Audit: Evidence from A Controlled Experiment in Minnesota", Journal of Public Economics, 79, 455-483.

Song, A. Y. \& Yarbrough, T. E. (1978), "Tax Ethics and Taxpayer Attitudes", Public Administration Review, 38(5), 442-452.

Stefura, G. (2012), "The Role Played by Economic and Noneconomic Variables in The Analysis of Tax Compliance", Review of Economic and Business Studies, Alexandru Ioan Cuza University, Faculty of Economics and Business Administration, 9, 105-120.

The Guardian, (2018), "UK Finally Takes On Arrogant Tech Giants with Digital Services Tax".

Torgler, B. \& Schneider, F. (2005), “Attitudes Towards Paying Taxes in Austria: An Empirical Analysis. Empirica, 32(2), 231-250.

Tusubira, F. N. \& Nkote, I. N. (2013), "Income Tax Compliance Among SMEs in Uganda: Taxpayers' Proficiencies Perspective", International Journal of Business and Social Science, 4(11), 133-143. 
Van den Bos, K., Peters, S. L., Bobocel, D. R. \& Ybema, J. F. (2006), “On Preferences and Doing the Right Thing: Satisfaction with Advantageous Inequity When Cognitive Processing Is Limited”, Journal of Experimental Social Psychology, 42(3), 273-289.

Van Dijke, M. \& Verboon, P. (2010), "Trust in Authorities as A Boundary Condition to Procedural Fairness Effects On Tax Compliance", Journal of Economic Psychology, 31, Elsevier, 80-91.

Varma, K. N. \& Doob, A. N. (1998), “Deterring Economic Crimes: The Case of Tax Evasion”, Canadian Journal of Criminology, 40(2), 165-184.

Verberne, J. (2018), "Taxation and the Informal Business Sector in Uganda", Journal of Accounting and Taxation, 5(April 2018), 1-21.

Verboon, P. \& Goslinga, S. (2009), "The Role of Fairness in Tax Compliance”, Netherlands Journal of Psychology, 65(4), 136-145.

Walster, E., Walster, G. W. \& Berscheid, E. (1978), “Equity: Theory and Research”, Boston: Allyn and Balcon.

Wenzel, M. (2002), "An Analysis of Norm Processes in Tax Compliance”, The Australian National University. Center for Tax System Integrity, Working paper 33.

Wenzel, M. (2002), "The Impact of Outcome Orientation and Justice Concerns On Tax Compliance: The Role of Taxpayers' Identity”, Journal of Applied Psychology, 87(4), 629-645.

Wenzel, M. (2003), “Tax Compliance and The Psychology of Justice: Mapping The Field”, In V. Braithwaite (Ed.), Taxing Democracy: Understanding Tax Avoidance and Evasion (41-69). Aldershot, UK: Ashgate.

Wenzel, M. (2004), “An Analysis of Norm Processes in Tax Compliance”, Journal of Economic Psychology, 25(2), 213-228.

Yitzhaki, S. (1974), A Note On Income Tax Evasion: A Theoretical Analysis. Journal of Public Economics, 3(2), 201-202. 